rubella infection in the offspring of a high proportion of women who had been exposed to clinical disease (Peckham, 1972) a similar proportion of subclinical cases would have been included in the "non-rubella" group.

The findings described here support the observations of McDonald and Peckham (1967), and it seems that patients with serologically diagnosed rubella in whom no rash had occurred after immunoglobulin had been given were not at the same risk as those exposed to clinical disease. It is possible that some of the subclinical attacks were, in fact, reinfections and that the methods of serological testing used in this large-scale trial were not adequate to detect extremely low levels of rubella antibody resulting from infection earlier in life. On the other hand, modification of the disease process by immunoglobulin may have prevented placental infection and subsequent fetal damage.

Brown (1968) found that immunoglobulin did not reduce the incidence of rubella in susceptible women but suppressed the clinical manifestations of the disease. He found that damage to the fetus after maternal infection in the first trimester occurred in only one of the 14 pregnancies where immunoglobulin was administered compared with four out of 27 pregnancies of uninoculated women, 20 of whom were infected after the first trimester.

The distinction between subclinical primary infection and reinfection may be extremely difficult to make by measurement of serum H.I. or neutralizing rubella antibody in paired samples of sera. In cases of reinfection there is usually a rise in rubella H.I. antibody depending on the initial titre, but this is shown by a rise in the IgG and not in the IgM as it is in a primary infection. This distinction is important as reinfection is not known to be associated with congenital rubella. Boué (1971) examined the problem of reinfection by following up the offspring of three women exposed to rubella in pregnancy in whom there was a significant rise in total rubella H.I. antibody which was confined to the IgG fraction. He found that the children were without defects and showed no serological or virological evidence of intrauterine rubella infection.

In the present study $53 \%$ of children exposed to clinical rubella in utero showed evidence of intrauterine infection and there was a close correlation between the presence of rubella antibody and a defect. These findings were similar to those of a previous study, in which at examination between 1 and 4 years of age of 218 children exposed to clinical rubella in pregnancy after the use of immunoglobulin $54 \%$ were shown to have detectable rubella antibody (Peckham, 1972). In that study, however, the diagnosis of rubella in the mother had been made on clinical grounds alone.

The limitations to the use of immunoglobulin are many. A high proportion of women will be unaware that they are pregnant in the early months when the fetus is at greatest risk and so will not seek advice after contact with rubella. Secondly, the primary contact may not be known as rubella is often subclinical. The interval between contact and administration of immunoglobulin is important as is also the variation of antibody titre in different batches of immunoglobulin. For these reasons immunoglobulin is bound to be of limited usefulness in the prevention of rubella defects. Nevertheless, until the effect of mass vaccination is fully evaluated large doses of immunoglobulin of high titre antibody could be used for susceptible women in contact with rubella in early pregnancy because there will always be a number of pregnant women exposed to rubella who do not wish to have the pregnancy terminated. In these cases immunoglobulin may be beneficial but it is essential that if it is used serological testing must be done to determine whether the pregnant woman has escaped infection.

I should like to thank the members of the working party on rubella for permission to examine the children; Dr. E. Vandevelde for testing some of the sera; Professor J. A. Dudgeon, Dr. W. C. Marshall, and Dr. T. Pollock for their constant interest, help, and advice; children's general practitioners for their co-operation; the paediatricians who kindly examined some of the children; and Mr. G. Hawkins for his technical help.

\section{References}

Boué, A., Nicolas, A., and Montagnum, B. (1971). Lancet, 1, 1251.

Brown, G. C. (1968). Proceedings of the Society for Experimental Biology and Medicine, 127, 340.

Dudgeon, J. A., et al. (1971). The Practitioner, 207. 782.

McDonald, J. C., and Peckham, C. S. (1967). British Medical fournal, 3, 633. Marshall, W. C., Peckham, C. S., Darby, C. P., Dudgeon, J. A., and Hawkins, G. T. (1971). The Practitioner, 207, 632 .

Peckham, C. S. (1972). Archives of Disease in Childhood, 47, 571.

Public Health Laboratory Service Working Party on Rubella (1970). British Medical fournal, 2, 497.

\title{
Amitriptyline and Imipramine Poisoning in Children
}

\author{
K. M. GOEL, R. A. SHANKS
}

British Medical fournal, 1974, 1, 261-263

\section{Summary}

The increasing number of children admitted to this hospital with poisoning by tricyclic antidepressants is causing concern. Of 60 children admitted between January 1966 and July 1973, half were admitted in the last 18 months. In $60 \%$ of these patients the tricyclic com-

Royal Hospital for Sick Children, Glasgow G3 8SJ

K. M. GOEL, M.D., M.R.C.P., Senior Registrar in Paediatrics R. A. SHANKS, M.D., F.R.C.P., Consultant Paediatrician

pounds had been prescribed for nocturnal enuresis. One child aged 2 years and 4 months died of imipramine poisoning. It is imperative that all children with poisoning by tricyclic compounds, irrespective of the dosage, are admitted to hospital for continuous cardiac monitoring. Cardiac arrhythmias induced in children by amitriptyline and imipramine are prominent and dangerous.

In the earlier years of this survey the antidepressants taken by children had usually been prescribed for adults, but recently they have been increasingly prescribed as a treatment for enuresis in children themselves. Medicine for a trivial complaint is unlikely to be regarded by parents as potentially dangerous and practitioners should therefore warn them accordingly; if, indeed, the transient efiect of these potentially dangerous drugs upon the average case of bed-wetting in childhood can be justified. 


\section{Introduction}

The unexpectedly severe effect on children of poisoning with the tricyclic antidepressants amitriptyline hydrochloride and imipramine hydrochloride has been stressed by Steel et al. (1967). More children are being admitted to this hospital with severe symptoms of poisoning from these drugs, and this seems to be associated with their increasing use in the treatment of enuresis. This paper re-emphasizes the dangers of these drugs in children in the light of our recent experience, and expresses our doubts whether they should be given in the average case of enuresis.

\section{Patients and Methods}

From January 1966 to July 1973 a total of 60 children-29 girls and 31 boys - were admitted to the medical wards with amitriptyline hydrochloride or imipramine hydrochloride poisoning. Three-quarters of them were between 2 and 4 years old, which corresponds with the pattern usually seen in cases of accidental poisoning in children. In 34 cases $(56.6 \%)$ tricyclic antidepressants had been prescribed for siblings (18 cases) or for the patients themselves (16 cases) for nocturnal enuresis. In 26 cases $(43.3 \%)$ they had been prescribed for depressive states in adult members of the family: for the mother in 15 cases, a grandparent in 5 cases, and an aunt in 6 cases (table' $I$ ). Cases of poisoning with these drugs when prescribed for nocturnal enuresis have steadily increased in number since 1969 (see chart).

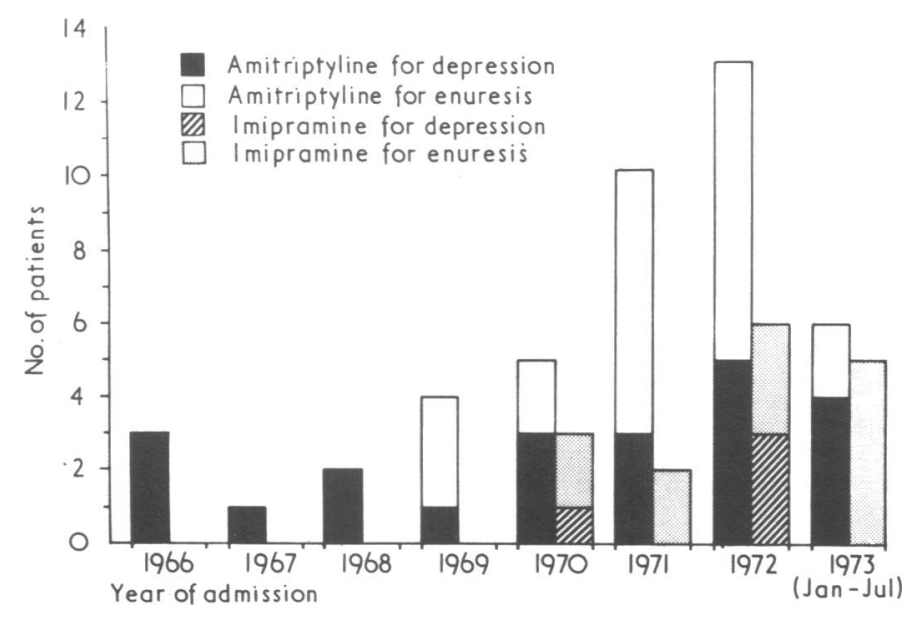

Incidence of amitriptyline hydrochloride and imipramine hydrochloride poisoning from January 1966 to July 1973.
The incidence of sinus tachycardia among cardiac abnormalities (table II) and the incidence of ataxia, hallucinations, and nystagmus was higher in children with amitriptyline poisoning, while mydriasis, dysarthria, retention of urine, and cardiac irregularities were commoner with imipramine poisoning (tables II and III). The symptoms usually developed within four hours of ingestion of the drug.

TABLE II-Cardiovascular Features of Amitriptyline and Imipramine Poisoning in the 60 Patients

\begin{tabular}{|c|c|c|c|}
\hline & $\begin{array}{l}\text { Amitriptyline } \\
\text { Hydrochloride }\end{array}$ & $\begin{array}{l}\text { Imipramine } \\
\text { Hydrochloride }\end{array}$ & $\begin{array}{l}\text { Total No. } \\
\text { of Patients }\end{array}$ \\
\hline Sinus tachycardia $\quad \ldots$ & $24(120-180 /$ & $12(120-180 /$ & 36 \\
\hline $\begin{array}{l}\text { Sinus arrythmia } \ldots \\
\text { Ventricular premature systoles } \\
\text { Conduction disturbances } \\
\text { Hypotension .. } \\
\text { Cardiorespiratory arrest }\end{array}$ & $\begin{array}{l}2 \\
2 \\
0 \\
1 \\
1\end{array}$ & $\begin{array}{l}2 \\
1 \\
2 \\
2 \\
2\end{array}$ & $\begin{array}{l}4 \\
3 \\
2 \\
3 \\
3\end{array}$ \\
\hline
\end{tabular}

TABLE III-Neurological and Atropinic Features of Amitriptyline and Imipramine Poisoning in the 60 Patients

\begin{tabular}{|c|c|c|c|c|c|}
\hline & & & $\begin{array}{l}\text { Amitriptyline } \\
\text { Hydrochloride }\end{array}$ & $\begin{array}{l}\text { Imipramine } \\
\text { Hydrochloride }\end{array}$ & $\begin{array}{l}\text { Total No. } \\
\text { of Patients }\end{array}$ \\
\hline \multicolumn{3}{|c|}{$\begin{array}{l}\text { Drowsiness } \\
\text { Agitation and/or restlessness }\end{array}$} & \multirow{12}{*}{$\begin{array}{r}36 \\
17 \\
16 \\
5 \\
9 \\
8 \\
1 \\
6 \\
4 \\
2 \\
3 \\
1 \\
2\end{array}$} & \multirow{12}{*}{$\begin{array}{r}12 \\
7 \\
1 \\
8 \\
3 \\
3 \\
2 \\
2 \\
1 \\
2 \\
0 \\
1 \\
0\end{array}$} & \multirow{12}{*}{$\begin{array}{r}48 \\
24 \\
17 \\
13 \\
12 \\
11 \\
3 \\
8 \\
5 \\
4 \\
3 \\
2 \\
2\end{array}$} \\
\hline Ataxia : . . & . & . & & & \\
\hline Mydriasis & . & .. & & & \\
\hline Vomiting & $\therefore$ & $\because$ & & & \\
\hline Flushing of face & . & .. & & & \\
\hline Coma : . . & . & .. & & & \\
\hline Convulsions $\quad$. & $\ldots$ & . & & & \\
\hline Hyperreflexia. & . & . & & & \\
\hline Retention of urine & .. & .. & & & \\
\hline Hallucinations .. & . & . & & & \\
\hline Dysarthria $\quad \ldots$ & .. & $\ldots$ & & & \\
\hline Nystagmus & $\ldots$ & .. & & & \\
\hline
\end{tabular}

On clinical findings the 60 patients were classified as mildly, moderately, or severely affected (table IV). The 35 patients classified as mildly affected had symptoms of drowsiness, restlessness, flushing of face, hallucinations, vomiting, mydriasis, and sinus tachycardia, while 22 patients classified as moderately affected presented with ataxia, convulsions, dysarthria, nystagmus, hyperreflexia, a positive Babinski sign, and systolic hypertension. The symptoms of the remaining three severely poisoned children were characterized by coma, convulsions, hypotension, electrocardiographic abnormalities, and cardiorespiratory arrest. The amount of tricyclics taken in 18 of the 60 patients was unknown but in 42 cases the parents were able to estimate the amount. The minimum lethal dose for both the

TABLE I-Drugs Ingested by the 60 Patients

\begin{tabular}{|c|c|c|c|c|c|c|c|c|c|c|c|}
\hline & & & & & & & & \multirow{2}{*}{ No. of Patients } & \multicolumn{2}{|c|}{ Reason Prescribed } & \multirow{2}{*}{ Outcome } \\
\hline & & & & & & & & & Enuresis & Depression & \\
\hline \multirow[t]{2}{*}{$\begin{array}{l}\text { Amitriptyline hydrochloride } \\
\text { Imipramine hydrochloride }\end{array}$} & $\begin{array}{l}\ldots \\
\therefore\end{array}$ & $\therefore$ & 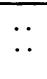 & $\begin{array}{l}\cdots \\
\cdots\end{array}$ & $\begin{array}{l}\cdots \\
\cdots\end{array}$ & $\ddot{x}$ & $\ldots$ & $\begin{array}{l}44 \\
16\end{array}$ & $\begin{array}{l}22 \\
12\end{array}$ & $\begin{array}{r}22 \\
4\end{array}$ & $\begin{array}{l}44 \text { Recovered } \\
15 \text { Recovered } \\
1 \text { Died }\end{array}$ \\
\hline & & tal & & & & & & 60 & 34 & 26 & 60 \\
\hline
\end{tabular}

TABLE IV-Severity of Symptoms and Amount of Drug Ingested by the 60 Patients

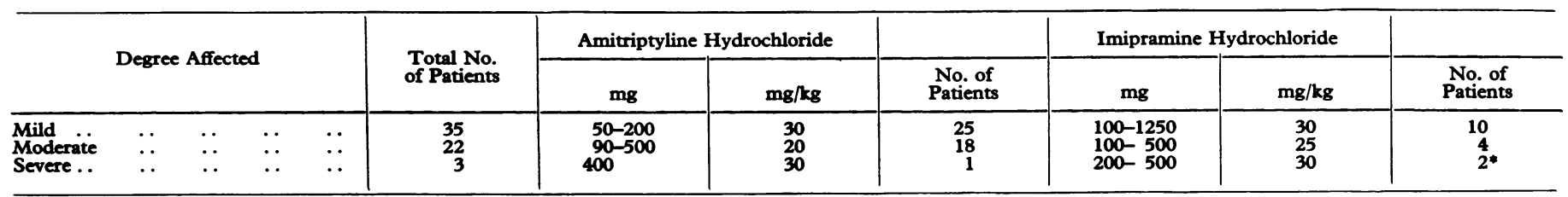

* One child died 4 hours after ingestion of imipramine $15 \mathrm{mg} / \mathrm{kg}$. 
tricyclic antidepressants is probably $30 \mathrm{mg} / \mathrm{kg}$ body weight (table IV), though no direct correlation has been noted between the degree of toxicity and the amount of drug ingested. This variation could possibly be due to the difficulty in obtaining an accurate history from the parents and therefore in establishing with certainty the exact amount of the drug ingested.

Most of the patients with mild and moderate poisoning were monitored electocardiographically and all recovered spontaneously within 24 hours without any sequelae. The three children with severe poisoning (aged 27 months, 15 months, and 17 months) who took imipramine $15 \mathrm{mg} / \mathrm{kg}, 45 \mathrm{mg} / \mathrm{kg}$, and amitriptyline $30 \mathrm{mg} / \mathrm{kg}$ respectively required mechanical respiratory control and were connected to Engström intermittent positive pressure ventilators. Ventricular premature systoles were present in all three and were controlled by lignocaine $0.5 \mathrm{mg}-1 \mathrm{mg} / \mathrm{min}$ intravenously. Two of them showed ventricular tachycardia on electrocardiogram at some stage and were treated with intravenous procainamide $700 \mathrm{mg}$ and propranolol $2 \mathrm{mg}$ respectively, with noticeable improvement.

The two patients with severe imipramine poisoning showed conduction disturbances: complete heart block and complete right bundlebranch block. An intravenous cardiac pacemaker was inserted in both but the patient who had ingested imipramine $15 \mathrm{mg} / \mathrm{kg}$ died 4 hours later. The other two patients, one with imipramine poisoning and the other with amitriptyline poisoning, survived without sequelae. The incidence of convulsions was the same with both the tricyclic drugs. Convulsions occurred in eight patients and were controlled with diazepam $0.2 \mathrm{mg} / \mathrm{kg}$ intravenously.

\section{Discussion}

Of the 60 patients admitted from January 1966 to July 1973, 30 were admitted during the last 18 months and in $60 \%$ of these cases tricyclic antidepressants had been prescribed for nocturnal enuresis (see chart). This was probably a result of reports of their value in the treatment of this condition (Epstein and Guilfoyle, 1965; Kardash et al., 1968; Esperanca and Gerrard, 1969; Martin, 1971; Fraser, 1972; Kolvin et al., 1972). In our series however, parents seemed quite unaware of the potential dangers of these drugs.

In view of the lack of a definite quantitative assessment of their toxicity, children who ingest tricyclics in whatever dosage should always be admitted for observation and continuous cardiac monitoring for 24 hours, because arrythmias in these cases are common and dangerous. In our experience, if the child is able to survive the critical first 24 hours recovery is likely, because it is during this period that most of the drug is metabolized. Some authors have suggested that serious manifestations invariably appear after the ingestion of $20 \mathrm{mg} / \mathrm{kg}$ of imipramine or amitriptyline or even less (Steel et al., 1967; Brown et al., 1971; Young and Galloway, 1971). Matthew and Lawson (1967), however, suggest that the severity of poisoning is largely related to the tolerance of the individual and therefore the severity should be assessed on the clinical picture rather than on the alleged dose. Furthermore, the blood and urine levels of these drugs do not indicate the severity of poisoning and they help only in verifying the diagnosis biochemically (Noble and Matthew, 1969).

Because there is no known antidote, the management of poisoning with the tricyclics is mainly symptomatic. Gastric lavage is the only method of removing the drug and it should be perfomed with the usual precautions. The amount of tricyclic drugs and their metabolites recovered by forced diuresis, peritoneal dialysis, and haemodialysis is so small that these procedures are of little value (Harthorne et al., 1963; Sunshine and Yaffe, 1963; Rasmussen, 1965; Halle and Collipp, 1969).

If, as seems likely, tricyclic antidepressants maintain their reputation as effective drugs in the management of organic depression in adults it remains essential that these, and other potentially dangerous drugs, are kept out of the reach of children. Their use in the treatment of childhood enuresis, however, raises more pressing problems. Reactions of parents to their enuretic children range from anger to mild anxiety: few regard the condition as serious and consequently regard medicines prescribed for the condition as being without danger. The parents of two of our patients having rather unwillingly brought one child to hospital, had to be coerced into bringing the other for whom the medicine had been originally prescribed. She had also helped herself to some extra dosage and on admission was more ill than her sister. The parents had no idea that the prescription had been any more than a "bottle for bed-wetting."

Clearly parents must be warned very carefully of the dangers of these drugs. We wonder how many intelligent parents would accept the risk of a potentially dangerous drug in the treatment of an almost invariably self-limiting and non-fatal disorder, particularly when the tricyclic antidepressants receive only a luke-warm recommendation in current paediatric practice and it is generally agreed that their effect is only transient (Forfar and Arneil, 1973; Editorial, B.M.J., 1973).

We are grateful to our colleagues for permission to study patients under their care.

\section{References}

Brown, T. C. K., Dwyer, M. E., and Stocks, J. G. (1971). Medical fournal of Australia, 2, 848.

(1973). British Medical fournal, 2, 69.

Epstein, S. J., and Guilfoyle, F. M. (1965). American fournal of Diseases of Children, 109, 412.

Esperanca, M., and Gerrard, J. W. (1969). Canadian Medical Association Fournal, 101, 721.

Forfar, J. O., and Arneil, G. C. (1973). Textbook of Paediatrics, p. 1729. Edinburgh, Churchill Livingstone.

Fraser, M. S. (1972). Practitioner, 208, 203.

Halle, M. A., and Collipp, P. J. (1969). New York State fournal of Medicine, 268, 33.

Kardash, S., Hillman, E. S., and Werry, J. (1968). Canadian Medical Association fournal, 99, 263.

Kolvin, I., et al. (1972). Developmental Medicine and Child Neurology, 14, 715.

Martin, G. I. (1971). American fournal of Diseases of Children, 122, 42.

Matthew, H., and Lawson, A. A. H. (1967). Treatment of Common Acute Poisonings. Edinburgh, E. and S. Livingstone.

Noble, J., and Matthew, H. (1969). Clinical Toxicology, 2, 403.

Rasmussen, J. (1965). Lancet, 2, 850.

Rasmussen, J. (1965). Lancet, 2, 850.

Sunshine, P., and Yaffe, S. J. (1963). American fournal of Diseases in Children, 106, 501 .

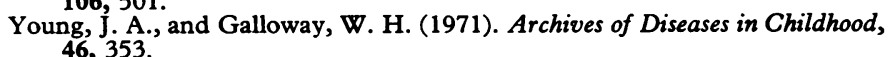

